https://doi.org/10.25143/socr.16.2020.1.064-075

\title{
Vizuālā tēla neaizskaramības sociāli bioloǵiskie apsvērumi
}

\author{
Sabīne Krilova \\ ORCID: 0000-0003-0515-4554 \\ Latvijas Universitāte, Latvija \\ sk18128@students.lu.lv \\ Mg. biol., Mg. env. sc. Andris Ziemelis \\ ORCID: 0000-0003-0629-3732 \\ Latvijas Universitāte, Latvija \\ az08112@students.lu.lv
}

\section{Kopsavilkums}

Cilvēka vizuālais tēls iemanto apjomīgu sociāli biologiskās informācijas daudzumu. Tas norāda uz dzimumu, vecumu, rasi, veselības stāvokli, auglību, hormonu līmeni un pat uz paredzamo uzvedību un dzīves ilgumu. Tā ir būtiska privātā informācija, kas ikdienā nav aizsargāta un kas ir eksponēta apkārtējiem. Latvijā katrs trešais skolēns saskaras ar mobingu, un tas ir viens no augstākajiem rādītājiem starp Ekonomiskās sadarbības un attīstības organizācijas valstīm. Piemēram, visticamāk, tieši mobings bijis par iemeslu 16 gadu veca puiša pašnāvībai, kas notika 2019. gadā. Zināms, ka pašnāvība ir sociālās atstumtības rezultāts, un Latvijā ir trešais lielākais pašnāvību izdarījušo cilvēku skaits Eiropas Savienībā.

Rakstā tiek analizēta vizuālā tēla sociāli biologiskā koncepcija, sniegti argumenti tā aizsardzībai un nozīmīgumam sabiedrībā kopsakarā ar spēkā esošajām tiesību normām un judikatūru. Nobeigumā ir priekšlikums, kas attiecināms uz likumprojektu "Sejas aizsegšanas ierobežojuma likums”, kā arī uz sejas atpazī̌anas videonovērošanas sistēmas iespējamu ieviešanu.

Atslēgvārdi: pamattiesības, tiesību subjekts, Sejas aizsegšanas ierobežojuma likums, sejas atpazīšana, seksapīls, vizuālie signāli. 


\section{levads}

Neatkarīgi no tiesiskā regulējuma un tā izmaināàm vizuālā tēla signāli būtiski ietekmē cilvēku savstarpējo komunikāciju. Neapzināti, taču citu indivīdu ārējais izskats, t. sk. žesti, stāja un apǵērbs, ietekmē apkārtējo cilvēku uzvedību [18, 437]. Izskatam ir svarīga sociāli biolog̣iska nozīme, jo ikviena indivīda izskats ir genētiskā materiāla atspulgs [30, 53], piemēram, cilvēka sejas pievilcība ir skaidrojama ar labu gēnu esamību, kas vizuāli izpaužas augstā sejas simetrijas indeksā [56, 1915]. Arī citas skaistuma iezīmes, kas izpaužas dzimumu seksuālā pievilcībā $[69,155]$, ir skaidrojamas ar genētiku un evolucionāro nozīmi paaugstināt izdzīvošanas spējas [16, 253-263].

Sabiedrībai ir biologiiska tieksme atstumt indivīdus, kuriem ir nepiemēroti gēni, tādējādi mazinot iespēju, ka pēcnācējiem būs zemas izdzīvošanas iespējas [67, 83], kā arī mazinot slimību izplatības riskus. Autoimūno slimību, tādu kā, piemēram, psoriāze [45, 54], ārējo izpausmju dēl pacienti bieži cieš emocionāli, jo jūtas sociāli atstumti [51].

Latvijā katrs trešais skolēns saskaras ar mobingu, kas ir viens no augstākajiem rādītājiem starp Ekonomiskās sadarbības un attīstības organizācijas valstīm [62, 16-17]. Piemēram, visticamāk, tieši mobings bijis par iemeslu 16 gadu veca puiša pašnāvībai, kas notika 2019. gadā [50]. Zināms, ka pašnāvība ir sociālās atstumtības rezultāts [55, 209-211], un Latvijā ir trešais lielākais pašnāvību veikušo cilvēku skaits Eiropas Savienībā [39].

Tādējādi var secināt, ka demokrātiskā tiesiskā valstī būtu jāapsver indivīdu privāttiesību aizsardzības un sabiedrības labklājības nodrošināšanas risinājumi.

Šì darba mērḳis ir apsvērt pamattiesību subjekta tiesības uz vizuālā tēla neaizskaramību.

Lai realizētu mērḳi, izvirzìti vairāki uzdevumi:

- noskaidrot vizuālā tēla sociāli biologiisko jēdzienu un tā nozìmi;

- izvērtēt biologiskā tēla aizsardzības iespējas un argumentus;

- veikt secinājumus un sniegt ierosinājumus.

Darbā izmantotās zinātniskās pētniecības metodes ir šādas: vēsturiskā metode, analītiskā metode, salīdzinošã metode un abstrakti logiskā metode.

\section{Vizuālā tēla sociāli bioloǵiskais jēdziens un tā nozīme}

Saskaṇā ar sociālās mācīšanās teoriju ikviens indivīds ir neatrauta sabiedrības sastāvdaḷa, kura no piedzimšanas brīža savu uzvedību, paradumus un uzskatus veido, pamatojoties un ņemot vērā apkārtējos indivīdus [12, 180-186]. Atbilstīgi šai teorijai, piemēram, jaunieši, apskatot to informācijas daḷu, kas pieejama sociālajos tīklos, veido savu pasaules izpratni un cenšas līdzināties saviem elkiem, kuriem škietami ir augstas reproduktīvās spējas un sociālais statuss. Tieši reprodukcija ir viens no svarīgākajiem sugas izdzīvošanas mehānismiem [7, 316-360]. Dzīvo radību, t. sk. cilvēka, bioloğiskā jēga ir izdzìvot, vairoties un attīstîties. Bez šiem pamatuzdevumiem neviena suga līdz 
mūsdienām neizdzìvotu. Arī cilvēki ne. Tādēḷ veiksmīgi vairoties ir tik svarīgi. Darvins aprakstīja, ka ne visi sugas indivīdi vienlīdzīgi piedalās reproduktīvajā procesā, viṇš izklāstijja seksuālās atlases teoriju, kurā noteikts, ka viena dzimuma indivīdi konkurē un sacenšas, lai nākamai paaudzei nodotu stiprākos gēnus, tādējādi paaugstinot sugas izdzīvošanas spējas $[15,87-90]$.

Arī starp cilvēkiem ir indivīdi, kuri liekas seksīgāki par citiem, un šie indivīdi nav vienlīdzīgi savās reproduktīvajās iespējās $[19,30]$. Vīriešus piesaista jaunas sievietes ar gludu ādu, gariem, mīkstiem matiem, lielām acīm, slaidiem ḳermen,iem, garām kājām, platiem gurniem, lielām un izteiktām krūtīm, apaliiem dibeniem un plakaniem vēderiem [61, 553-561; 68, 299-304]. Savukārt sievietes piesaista gari, atlētiski vīrieši ar vidēji muskuḷotām rokām un kājām, platiem pleciem, mazu tauku īpatsvaru, izteiktu apakšžokli un reljefu vēdera muskulatūrā [21, 83-85].

Kāpēc cilvēki tērē tik daudz laika, pūḷu un naudas savam izskatam? Kāpēc daži cilvēki šķiet pievilcīgāki par citiem? Tas skaidrojams ar to, ka cilvēka vizuālais tēls iemanto apjomīgu sociāli biologisku informācijas daudzumu. Tas norāda uz dzimumu, vecumu, rasi, veselības stāvokli, auglïbu, hormonu līmeni un pat uz paredzamo uzvedību un dzīves ilgumu. Tā ir būtiska privātā informācija, kas ikdienā nav aizsargāta un kas ir eksponēta apkārtējiem.

Par to liecina turpmāk vairākas pētījumos gūtās atziṇas.

Pirmkārt, pētỉjumos secināts, ka ir būtiska sakarība starp sejas izskatu un indivīda veselības stāvokli, vitalitāti un auglību. Piemēram, atklāts, ka gan vīrieši, gan sievietes, kuru sejas vērtētas kā vispievilcīgākās, dzìvo ilgāk [31,354]. Sievietēm pievilcīgāki škịiet tie vīrieši, kuri ir būtiski auglīgāki [60, 203-205]. Ir konstatēta pat inteligences un auglỉbas korelācija $[8,279-280]$ un tendence, ka cilvēkiem ar pievilcīgu seju ir augstāks IQ [70, 243-245]. Paredzams arī, ka pievilcīgai sievietei būs augstāks estrogēna līmenis un laba reproduktīvā veselība [59, 137-138]. Secināts, ka pēc sejas izskata var veidot priekšstatu par genētisko rezistenci pret slimībām [14, 219-221]. Gan vīriešiem, gan sievietēm ar pievilcīgu seju ir augsts sejas simetrijas indekss, kas ir vienlaicīgi arī veselības mērs [28, 236-238]. Tiek norādīts, ka tikai dažas minūtes veci zīdainni ir paḳ̣auti sejai lïdzīgiem stimuliem, reageējot uz sejai līdzīgiem priekšmetiem [38, 9-10]. Kopumā cilvēks paḷaujas uz sejas izskatu, lai atpazītu daudzas personas, ar kurām saskaras savā dzīvē [13, 318]. Ir noteikts, ka cilvēks dzīves laikā spēj atpazìt 5000 sejas [37, 5].

Otrkārt, vērtējot vizuālo tēlu ne tikai saistībā ar sejas izskatu, jāṇem vērā, ka cilvēkam ir būtiskas dzimuma atšḳirības ḳermeṇa konfigurācijā, t. i., seksuāli dimorfiskas atšķirības [44, 363-369]. Sieviešu figūrām mēdz būt smilšu pulksteņa forma. Noteikts, ka pievilcīgākā vidukḷa un gurnu proporcija ir 0,7 [57, 299]. Pat tie vīrieši, kuri ir dzimuši akli, dod priekšroku šādai vidukḷa un gurnu attiecībai [41, 184]. Konstatēts, ka sievietēm ar zemāku vidukḷa un gurnu proporciju ir labākas reproduktīvās iespējas, piemēram, viṇām notiek biežāka ovulācija [35, 1215], ir regulārāks menstruālais cikls [32, 1396], kā arī viñas ir veselīgākas - ir mazāks risks saslimt ar sirds un asinsvadu slimībām, sirdstrieku, diabētu, žultspūšḷa, nieru slimībām un vēzi [58, 344-345]. Smilšu pulksteṇa forma kalpo 
kā svarīgs reproduktīvs signāls arī citos veidos [34, 176-177], piemēram, sievietes vidukḷa un gurnu proporcija liecina par to, vai viņai ir grūtniecība, jo vēdera palielināšanās, kas notiek grūtniecības laikā, noved pie šīs proporcijas zaudēšanas. Platie gurni norāda arī uz iegurņa skeleta anatomiju un spēju sievietēm diezgan viegli dzemdèt.

Mūsu kultūrā paaugstināts tauku īpatsvars ierobežo reproduktīvās iespējas. Varētu būt, ka viens no lielākajiem noslēpumiem evolucionārajā psihologiijā ir tas, ka industrializētajās sabiedrībās priekšroka tiek dota slaidumam, turpretim neindustrializētajos reǵionos kā pievilcīgas tiek vērtētas sievietes ar visai augstu ḳermeņa tauku îpatsvaru $[64,316]$. Neatkarīgi no tã ir secināts, ka meitenēm pubertātes iestāšanās lielā mērā ir atkarīga no noteikta tauku ipatsvara līmeņa sasniegšanas (17\%) [24]. Turklāt jaunākas meitenes ar lieko svaru menstruāciju sasniedz agrāk. Turpretim būtisks svara zudums, ko izraisa fiziskas aktivitātes vai bads, bieži sievietēm izraisa neauglību, piemēram, kā tas ir anoreksijas gadījumā [40, 391-392].

Nepārprotami, vīriešiem lielas un izteiktas sieviešu krūtis liekas pievilcīgas. Pētījumos secināts, ka šāds uzskats varētu būt sekas saiknei starp sievietes ḳermeṇa tauku saturu un reprodukcijas spējām [26, 599-600]. Sievietēm ar lielām krūtīm ir paaugstināts estradiola līmenis un augstāka auglỉba $[35,1216]$, taču, sievietei novecojot un barojot zīdainusus, krūšu nozīme auglības identificēšanā mainās, krūtis zaudē tvirtumu [23, 204-205].

Vīriešiem parasti mēdz būt platāki pleci un šaurāki gurni, viṇu torsiem ir ḳịlveida forma, un sievietes šādus vīriešus vērtē kā pievilcīgus [17, 340], turklāt viniem ir augstāks testosterona līmenis [42, 469]. Pētījumos secināts, ka šādi zēni skolas laikā mēdz būt stiprāki un agresīvāki [25, 427], sāk agrāk nodarboties ar seksu un viṇiem ir vairāk dzimumpartneru [33, 299]. Jānorāda, ka muskulatūras veidošanai un uzturēšanai ir nepieciešama augsta enerğija un testosterona līmenis. Tā kā testosterons veicina imūno funkciju un palielināta muskuḷu masa ir saistīta ar augstas energijias pieejamību, muskuḷi signalizē par labu veselību un imūnsistēmu, turklāt spēja veidot lielāku muskuḷu masu ir daḷēji pārmantojama, kas liecina, ka priekšrocības, kas saistìtas ar muskulatūru, var tikt nodotas pēcnācējiem [22, 11-13]. Attiecībā uz muskuḷu masu starp dzimumiem ir būtiska atšķirība [43,324], kas liecina par to, ka priekšteču vīriešiem muskuḷ masa ir sniegusi priekšrocības medībās, resursu iegūšanā un vīriešu savstarpējā konkurencē $[52,169]$. Ir zināms, ka daudzi vīrieši vēlas kḷūt muskuḷotāki, lai būtu pievilcīgāki sievietēm un veiksmīgāki sacensībās ar citiem vīriešiem [22, 113]. Atbilstoši apgrieztā U hipotēzei sievietes mazāk piesaista vīrieši ar zemu vīriškīibas līmeni un arī ar lıti augstu līmeni, jo pārāk augsts testosterona līmenis var pasliktināt veselību, kā arī radīt neprognozējamu, nepatstāvīgu un agresīvu uzvedību, kas var radīt risku pašai sievietei $[22,4]$.

Treškārt, apmatojuma zaudēšana ir savdabīga iezīme, kas cilvēku padara atškirīgu no primātiem $[47,15]$. Ir vairāki iemesli, kāpēc tas vēsturiski ir noticis. Vienā no teorijām teikts, ka ir bijusi nepieciešamība efektīvāk atvēsināt pieaugošo smadzeṇu tilpumu, tādēl ḳermeṇa virsmas laukums varēja kalpot kā dzesētājs, lai pasargātu smadzenes no 
pārkaršanas [20, 343-344]. Savukārt citā teorijā teikts, ka apmatojuma zudums ir bijis selektīvs pielāgojums ektoparazītu invāzijas novēršanai [48, 118-119]. Ir zināms, ka, noṇemot kaunuma apmatojumu, būtiski samazinās kaunuma utu invāzijas izplatība, ko nevarētu teikt par seksuāli transmisīvo slimību izplatību [9, 265-266]. Lìdzīga analog̣ija varētu būt attiecībā uz subjektīvo nepatiku pret sejas apmatojumu.

N̦emot vērā to, ka kontakts ar ādu ir erogēns process, apmatojuma zaudēšana varēja būt selektīva, lai stiprinātu indivīdu tuvību starp partneriem vai starp māti un bērniem. Gludas, veselīgas ādas eksponēšana varēja kḷūt par signālu indivīda veselības stāvoklim un reproduktīvajām spējām, jo ādas kvalitāte ir svarīgs veselības un genētisko pielāgojumu indikators, kas norāda arī uz infekciju rezistenci [63, 308-309]. Bez apmatojuma ir ievērojami vieglāk novērtēt, vai personai uz ādas ir brūces, kukaiṇu kodumi, ādas slimības, parazìtiskas iezīmes un imūnsistēmas atbildes reakcijas uz iepriekšminēto. Daudzu slimību vai parazìtu ietekmes rezultātā āda spēj mainīt krāsu un struktūru, savukārt gluda, maiga āda norāda uz veselīgumu.

\section{Vizuālā tēla aizsardzības veidi un argumenti}

Nepieciešamība būt pievilcīgam var likt daudziem cilvēkiem justies neapmierinātiem ar savu izskatu [49, 721-724], un dažādās kultūrās vīrieši un sievietes vēsturiski ir izstrādājuši visdažādākos paṇēmienus, kā uzlabot savu pievilcību [19, 50-66], piemēram, korsetes nodrošina šaurāku vidukli un maina tā attiecību pret gurniem, tos padarot platākus, savukārt trenažieru zāles apmeklējumi ḷauj vīriešiem palielināt muskuḷainību un plecu platumu. Medicīnas sasniegumi l̦auj cilvēkiem atgriezt jaunību, kā arī modelēt savu formu un seju padarìt simetriskāku. Augšanas hormons un steroīdi l̦auj cilvēkiem augt garākiem un spēcīgākiem, pat spēj mainìt dzimumu. Arī kosmētika jau vēsturiski ir bijis visvienkāršākais veids, kā manipulēt ar cita indivīda uztveri. Savukārt apgēerbs nodrošina privāto daḷu nosegšanu no apkārtējo acīm.

Jau gadu tūkstošiem islāma religijiā ir noteikta un praktizēta vizuālā tēla aizsardzība [66, 196], nēsājot hidžābu, nikābu un burku. Apgēerbs ir visvienkāršākais veids, kā nodrošināt sava vizuālā tēla aizsardzību, taču, lai cik vienkārši būtu uzvilkt apgẹēbu, deviṇās Eiropas valstīs pastāv kāds nikāba un burkas valkāšanas aizliegums [65], bet Beḷgijā un Francijā publiskās vietās ir absolūts to valkāšanas aizliegums [54,30], vēl četrās valstīs tiek izstrādāti attiecīgie likumprojekti [65], t. sk. Latvijā.

Valsts sekretāru sanāksmē 2016. gada 22. septembrī tika pieteikts likumprojekts "Sejas aizsegšanas ierobežojuma likums" (turpmāk - likumprojekts) [54], ar kuru paredzēts būtiski ierobežot pamattiesību subjekta tiesības uz vizuālā tēla neaizskaramību, izvirzot mērḳi nodrošināt vienotas un harmoniskas sabiedrības pastāvēšanu, latviskās un eiropeiskās kultūrtelpas aizsardzību, kā arī atvērtu savstarpējo sabiedrības locekḷu saziṇu un kopā dzīvošanu, sekmējot sabiedrības drošību kopumā. Pēc Juridiskā biroja atzinuma [46] saņemšanas 2017. gada 14. novembrī likumprojekta izskatīšana 1. lasījumā tika atlikta, un lïdz šim brīdim tas vēl nav izskatìts. 
Jāpiebilst, ka vizuālā tēla aizsardzības veids var būt arī jebkura cita apgeērba veida dal̦as, piemēram, maskas, brilles u. c. dal̦as, kas nav attiecināmas uz religisko kontekstu.

Sejas atpazī̌̌anas algoritms spēj efektīvi atpazìt cilvēka sejas, tas ir starptautiski testēts, tiek lietots un ir atzìts par pietiekami labu tiktāl, cik tas neierobežo cilvēka pamattiesības. Šì tehnolog̣ija nodrošina identitātes automātisku noteikšanu. Vairākās pilsētās pastāv mākslīgā intelekta sejas atpazīšanas tehnoloǵijas izmantošanas aizliegums [36]. Savukārt pašreiz Latvijā iekšlietu ministrs Sandis G̣irğens apsver sejas atpazī̌̌anas videonovērošanas sistēmas ieviešanu, kas aktualizē jautājumu par cilvēktiesībām un privātumu kopsakarā ar ieguvumiem, ko gūs sabiedrība. Konkrēti priekšlikumi Ministru kabinetā šobrīd gan nav iesniegti, taču tiek organizētas darba grupas šì jautājuma risināšanai [27].

N̦emot vērā sociāli biologiskos apsvērumus, ikviena indivīda vizuālajam tēlam ir jābūt eksponētam, lai suga (sabiedrība) novērtētu indivīda pielāgošanās spēju un genētisko pārmantojamību, kā arī paredzētu tā uzvedību un spēju pretoties slimībām. Bet vissvarīgākais priekšnoteikums - lai atrastu piemērotu partneri pēcnācēju radīšanai. N̦emot vērā to, ka mūsdienās ir attīstīta medicīna un ka sabiedrībā ir noteikti attiecīgie tiesiskie akti un ētikas normas, kas ierobežo un regulē indivīda uzvedību, kas varētu apdraudēt citus, izškiroša nozīme indivīda vizuālā tēla novērtēšanai ir tikai pēcnācēja radīšanā. Ja indivīds nepiedalās pēcnācēju radīšanā, vērtēt viṇa vizuālo tēlu nav sabiedrības interesēs. Diemžēl notiek citādi - bērni, kuriem vēl nav iestājies reproduktīvais vecums, ir nežèlīgi pret citiem bērniem, kuri ir atškirīgi.

Šì problēma aktualizē pamattiesību subjekta tiesības uz vizuālā tēla neaizskaramību. No sociāli biolog̣iskajiem apsvērumiem izriet, ka indivīdam ir tiesības uz vizuālā tēla neaizskaramību, jo tam ir jānodrošina ne tikai vairošanās, bet arī izdzīvošana un attīstība, turklāt ikviens indivīds, arī nepiedaloties sugas veiksmīgā vairošanā, var būtiski nodrošināt sugas (sabiedrības) izdzīvošanu un attīstību.

Vizuālo tēlu apsedzoša apgēerba aizliegšana un sejas atpazišanas videonovērošanas sistēmas ieviešana būtu atbalstāma saskaṇā ar Eiropas Cilvēka tiesību un pamatbrīvību aizsardzības konvencijas [1] 8. panta otro punktu. Savukārt Satversmes 1. pantā nepārprotami uzsvērts, ka Latvija ir tiesiska valsts [11, 152], kurā ir spēkā vispārējo tiesību principi $[6,18]$, tostarp svarīgākie no tiem - samērīguma un tiesiskās paḷāvības jeb tiesiskās drošîbas principi $[6,18 ; 11,152]$. Līdz ar to likumdevējam, ievērojot Satversmes 1. pantā nostiprinātos tiesiskas valsts pamatprincipus, ir pienākums apsvērt, vai konkrētais tiesiskais regulējums ir efektīvs un vai tas nebūtu pilnveidojams [6, 28]. No tā secināms, ka likumdevējs var ierobežot cilvēka pamattiesības, ja vien tas ir samērojami ar sabiedrïbas ieguvumiem.

Likumprojekta "Sejas aizsegšanas ierobežojuma likums" anotācijā [54] nav minēti argumenti, kas skartu vizuālā tēla aizsardzību, pamatojoties uz sociāli biolog̣iskajiem apsvērumiem, bet gan izteikti argumenti, kas aprobežojas islāma reliǵijas kontekstā. Analog̣iski sociāli biologiskie apsvērumi būtu jāṇem vērā rosinājumiem ieviest sejas atpazišanas videonovērošanas sistēmas. Tādēḷ likumdevēja paustie argumenti ir pilnveidojami ar vizuālā tēla aizsardzības argumentiem, n,emot vērā sociāli bioloǵiskos apsvērumus, kuri minēti šajā darbā. 
Sabine Krilova, Andris Ziemelis. Vizuālā tēla

neaizskaramības sociāli biologiskie apsvērumi

\section{Pamattiesības uz vizuālā tēla neaizskaramību}

Pamattiesību subjektam ir tiesības uz vizuālā tēla neaizskaramību, pamatojoties uz šeit minētajiem apsvērumiem:

1) vizuālā tēla jautājums ir apskatìts Satversmes 96. panta [3; 4] un Eiropas Cilvēka tiesību un pamatbrīvību aizsardzības konvencijas 8. panta [1] tvērumā, kurā noteikta privātās dzīves neaizskaramība [10, 238];

2) Eiropas Cilvēktiesību tiesa lietu Armoniene pret Lietuvu un Biriuk pret Lietuvu spriedumos ir pamatojusi, ka personas dati par veselïbas stāvokli, īpaši un vēl jo vairāk informācija un fotoattēli, kas saistīti ar gimenes locekḷu saslimstību ar HIV, un to neatḷauta izpaušana presē var nodarìt ne tikai inficētās personas, bet arī visas gimenes privātuma ievērojamu aizskārumu [53,3]. Analoǵiski var secināt, ka vizuālais tēls, kas biolog̣iski sociālā veidā atspoguḷo indivīda veselības stāvokli, t. sk. iedzimtību, ir atzīstams par indivīda un gimenes privātuma datiem;

3) privātuma izpausme ir tiesības uz savu attēlu [10, 248], tās atvasināmas no Satversmē nostiprinātajām pamattiesībām un no speciālajos likumos par plašsaziņas līdzekḷu darbỉbas regulejjumu noteikto aizliegumu presei iejaukties personas privātajā dzivē [5, 7. pants]. Šìs tiesības būtu analogiski interpretējamas, kā tiesības uz savu vizuālo tēlu, jo attēls ir vizuālā tēla sastāvdaḷa;

4) Eiropas Parlamenta un Padomes 2016. gada 27. aprīla regulas (ES) 2016/679 par fizisku personu aizsardzību attiecībā uz personas datu apstrādi un šādu datu brīvu apriti 4. panta pirmajā dạ̣ā ir norādīts, ka personas dati ir jebkura informācija, kas attiecas uz identificētu vai identificējamu fizisku personu [2, 33]. N̦emot vērā to, ka vizuālais tēls ir dati, kuri neapšaubāmi nodrošina personas identificēšanu, šīs regulas mērḳis attiecināms arī uz vizuālā tēla aizsardzību;

5) ņemot vērā sociāli biologiskos apsvērumus par vizuālā tēla ietekmi uz personu un tās identitātes veidošanu, secināms, ka, nenodrošinot vizuālā tēla aizsardzību, indivīdam var tikt liegtas arī Satversmes [3; 4] 93., 95. un 102. pantā minētās tiesības. Satversmes 95. pantā ir iekḷaujams kaitējums, kas nodarīts kā psihiskas ciešanas, radot personai dziḷ aizvainojuma izjūtu [10, 206]. Ikvienas personas piedzimšana un būšana citādākam nav pašas personas griba [29, 21], tomēr ir gadījumi, kad persona visu savu dzīvi sañem apkārtējo cilvēku nepārtrauktus norādījumus un nosodījumu par attiecìgajām nepilnībām, pie kurām indivīds nav vainojams. Var tikt apdraudēta pat personas dzīvība (Satversmes 93. pants). Papildus jānorāda, ka cilvēka vizuālais tēls ir seksuālu stimulu kopums, kas var aktivizēt seksuālo uzvedību, kā rezultātā tas var izprovocēt seksuālu aktu, kas var kaitēt veselībai vai pat dzìvībai. Satversmes 102. pantā paredzētas tiesību subjekta biedrošanās tiesības [10, 396]. Nemot vērā apsvērumu, ka indivīds bieži tiek sociāli atstumts vizuālā tēla dēḷ [51], personai var tikt liegta šì iespēja. 


\section{Secinājumi}

1. Cilvēka vizuālais tēls iemanto apjomīgu sociāli biolog̣isku informācijas daudzumu. Tas norāda uz dzimumu, vecumu, rasi, veselības stāvokli, auglību, hormonu līmeni, pat prognozējamo uzvedību un dzīves ilgumu. Tā ir būtiska privāta informācija, kas ikdienā nav aizsargāta un kas ir eksponēta apkārtējiem.

2. Sugas biolog̣ijas kontekstā ikviena indivīda vizuālajam tēlam ir jābūt eksponētam bez ierobežojumiem, ar nosacījumu, ja tas piedalās gēnu nodošanā. Visos citos gadỉjumos pastāv pamattiesību subjekta tiesības uz vizuālā tēla neaizskaramību, tās pamatotas virknē tiesisko aktu par privātuma aizsardzību. Sociāli biologiskie apsvērumi l̦auj skaidrot un pastiprināt šis pamattiesības aizsardzības apsvērumus.

\section{Priekšlikums}

Latvijā kopš 2016. gada izstrādē esošais likumprojekts "Sejas aizsegšanas ierobežojuma likums", kura 2. panta pirmajā daḷā noteikts, ka "seju nav ațlauts aizsegt publiskā vietā [..]" [54], nav apstiprināms, jo sejas un k̦ermeņa aizsegšana ar apgeērbu ir vienīgais saprātīgais veids, kā aizsargāt pamattiesību subjekta tiesības uz vizuālā tēla neaizskaramību. Turklāt, vērtējot Eiropas Cilvēka tiesību un pamatbrīvību aizsardzības konvencijas [1] 8. panta otrajā punktā minēto par valsts drošîbas, sabiedriskās kārtības un labklājības interešu nodrošināšanu, likumdevējam nav nekāda būtiska pamata ierobežot minētās pamattiesību subjekta tiesības, jo nav saskatāmi draudi sabiedrībai indivīdu neidentificēšanas dēḷ.

\section{Pateicība}

Izsakām pateicību Latvijas Universitātes fondam par finansiālo atbalstu, kas pieškirts 2019./2020. akadēmiskajā gadā Alfrēda Raistera piemiñas stipendijas ietvaros.

\section{Socio-Biological Considerations of Integrity of Visual Image}

\section{Abstract}

Visual image of a man is a considerable amount of socially biological information. This includes gender, age, race, health, fertility, hormone levels, even behavior, and life expectancy. It is essentially private information that is not protected day-to-day basis and is rather exposed to the surrounding individuals. In Latvia, every third pupil faces bullying, which is one of the highest rates among OECD countries. For example, in 2019, 
it was more likely that bullying had been the reason for suicide of a 16-year-old boy. It is known that suicide is the result of social exclusion, and Latvia possesses the third largest number of people who have committed suicide in the European Union.

The article analyses socio-biological concept of visual image, arguments for its protection and its importance in society, compliance with existing legal provisions and case law. A proposal has been made for the establishment of legal provisions relating to the draft of the Facial Masking Limitation Law, as well as for the possible introduction of a facial recognition video surveillance system.

Keywords: fundamental rights, right holder, Facial Masking Limitation Law, facial recognition, sex appeal, visual releasers.

\section{Avoti un literatūra}

\section{Tiesību akti}

1. Cilvēka tiesību un pamatbrīvību aizsardzības konvencija: starptautisks dokuments, pieñemta 04.11.1950. Latvijas Vēstnesis. 143/144, 13.06.1997.

2. Eiropas Parlamenta un Padomes regula (ES) 2016/679 (2016. gada 27. aprïlis) par fizisku personu aizsardzību attiecībā uz personas datu apstrādi un šādu datu brīvu apriti un ar ko atcel direktīivu 95/46/EK (Vispārīgā datu aizsardzības regula). Eiropas Savienības Oficiālais Vēstnesis. L 119/1, 2016.

3. Grozijumi Latvijas Republikas Satversmē: Latvijas Republikas likums: pieñemti 15.10.1998. un stājās spēkā 06.11.1998. Latvijas Vēstnesis, 308/312, 23.10.1998.

4. Latvijas Republikas Satversme: Latvijas valsts likums: pieṇemta 15.02.1922. un stājās spēkā 07.11. 1922. Valdïbas Vēstnesis. 43, 01.07.1993.

5. Par presi un citiem masu informācijas līdzekliem: Latvijas Republikas likums: pieñemts 20.12.1990. un stājās spēkā 01.01.1991. Latvijas Republikas Augstākās Padomes un Valdïbas Ziņotājs. 5/6, 14.02.1991.

\section{Tiesu prakse}

6. Satversmes tiesa. 2014. gada 12. februāra spriedums lietā Nr. 2013-05-01 (2014). p. 29.

\section{Literatūra}

7. Alcock, J. (2009). Animal Behavior: An Evolutionary Approach, Ninth Edition. Star. Sinauer Associates.

8. Arden, R., Gottfredson, L. S., Miller, G., Pierce, A. (2009). Intelligence and Semen Quality are Positively Correlated. Intelligence. 37(3), 277-282. Iegūts no: doi.org/10.1016/j.intell.2008.11.001

9. Armstrong, N. R., Wilson, J. D. (2006). Did the "Brazilian" kill the pubic louse? Sexually Transmitted Infections. 82(3), 265-266.

10. Balodis, R. (2011). Latvijas Republikas Satversmes komentāri. VIII nodala. Cilvēka pamattiesības. Latvijas Vēstnesis.

11. Balodis, R. (2014). Latvijas Republikas Satversmes komentāri. Ievads. I nodaḷa. Vispärējie noteikumi. Latvijas Vēstnesis.

12. Bandura, A. (1977). Social Learning Theory. Prentice Hall.

13. Bruce, V., Young, A. (1986). Understanding Face Recognition. British Journal of Psychology. $77,305-327$. 
Sabine Krilova, Andris Ziemelis. Vizuālā tēla

neaizskaramības sociāli biologiskie apsvērumi

14. Craig, R. S., Little, A. C., Gosling, L. M., Perrett, D. I., Carter, V., Jones, B. C., Penton-Voak I., Petrie, M. (2005). MHC-Heterozygosity and Human Facial Attractiveness. Evolution and Human Behavior. 26(3), 213-226. Iegūts no: doi.org/10.1016/j.evolhumbehav.2004.09.002

15. Darwin, C. (1859). On the Origin of Species. London: Murray.

16. Darwin, C. (1871). The Descent of Man and Selection in Relation to Sex. John Murray.

17. Dijkstra, P., Buunk, B. P. (2001). Sex Differences in the Jealousy-Evoking Nature of a Rival's Body Build. Evolution and Human Behavior. 22(5), 335-341. Iegūts no: doi.org/10.1016/ S1090-5138(01)00070-8

18. Eibl-Eibesfeldt, I. (2007). Human Ethology. London and New York: Routledge Taylor \& Francis Group.

19. Etcoff, N. (1999). Survival of the Prettiest. New York: Anchor Books.

20. Falk, D. (1990). Brain Evolution in Homo: The Radiator Theory. Behavioral and Brain Sciences. 13(2), 333-344. Iegūts no: doi.org/10.1017/S0140525X00078973

21. Frederick, D. A., Fessler, D. M. T., Haselton, M. G. (2005). Do Representations of Male Muscularity Differ in Men's and Women's Magazines? Body Image. 2(1), 81-86. Iegūts no: doi.org/10.1016/j. bodyim.2004.12.002

22. Frederick, D. A., Haselton, M. G. (2007). Why is Muscularity Sexy? Tests of the Fitness Indicator Hypothesis. Personality and Social Psychology Bulletin. 33(8), 1167-1183. Iegūts no: doi.org/10.1177/0146167207303022

23. Frederick, D. A., Peplau, A., Leve, J. (2008). The Barbie Mystique: Satisfaction with Breast Size and Shape across the Lifespan. International Journal of Sexual Health. 20(3), 200-211. Iegūts no: doi.org/10.1080/19317610802240170

24. Frisch, R. E. (1984). Body Fat, Puberty and Fertility. Biological Reviews of the Cambridge Philosophical Society. 59(2), 161-188. Iegūts no: doi.org/10.1111/j.1469-185x.1984.tb00406.x

25. Gallup, A. C., White, D. D., Gallup, G. G. (2007). Handgrip Strength Predicts Sexual Behavior, Body Morphology, and Aggression in Male College Students. Evolution and Human Behavior. 28(6), 423-429. Iegūts no: doi.org/10.1016/j.evolhumbehav.2007.07.001

26. Gallup, G. G. (1982). Permanent Breast Enlargement in Human Females: A Sociobiological Analysis. Journal of Human Evolution. 11(7), 597-601. Iegūts no: doi.org/10.1016/ S0047-24.84(82)80007-9

27. G̦irǵens rosina Latvijā izvietot sejas atpazī̌anas kameras. (11.01.2020.) Apollo.lv. Iegūts no: https://www.apollo.lv/6870249/girgens-rosina-latvija-izvietot-sejas-atpazisanas-kameras

28. Grammer, K., Thornhill, R. (1994). Human (Homo sapiens) facial attractiveness and sexual selection: the role of symmetry and averageness. Journal of Comparative Psychology. 108(3), 233. Iegūts no: doi.org/10.1037/0735-7036.108.3.233

29. Harris, S. (2012). Free Will. Free Press.

30. Hartl, D. (2020). Essential Genetics and Genomics. Jones \& Bartlett Learning.

31. Henderson, J. J. A., Anglin, J. M. (2003). Facial Attractiveness Predicts Longevity. Evolution and Human Behavior. 24(5), 351-356. Iegūts no: doi.org/10.1016/S1090-5138(03)00036-9

32. Hooff, van, M. H. A., Voorhorst, F. J., Kaptein, M. B. H., Hirasing, R. A., Koppenaal, C., Schoemaker, J. (2000). Insulin, Androgen, and Gonadotropin Concentrations, Body Mass Index, and Waist to Hip Ratio in the First Years after Menarche in Girls with Regular Menstrual Cycles, Irregular Menstrual Cycles, or Oligomenorrhea. Journal of Clinical Endocrinology and Metabolism. 85(4), 1394-1400. Iegūts no: doi.org/10.1210/jc.85.4.1394 
Sabine Krilova, Andris Ziemelis. Vizuālā tēla

neaizskaramības sociāli biologiskie apsvērumi

33. Hughes, S. M., Dispenza, F., Gallup, G. G. (2004). Ratings of Voice Attractiveness Predict Sexual Behavior and Body Configuration. Evolution and Human Behavior. 25(5), 295-304. Iegūts no: doi.org/10.1016/j.evolhumbehav.2004.06.001

34. Hughes, S. M., Gallup, G. G. (2003). Sex Differences in Morphological Predictors of Sexual Behavior. Shoulder to Hip and Waist to Hip Ratios. Evolution and Human Behavior. 24(3), 173-178. Iegūts no: doi.org/10.1016/S1090-5138(02)00149-6

35. Jasieńska, G., Ziomkiewicz, A., Ellison, P. T., Lipson, S. F., Thune, I. (2004). Large Breasts and Narrow Waists Indicate High Reproductive Potential in Women. Proceedings of the Royal Society B: Biological Sciences. 271(1545), 1213-1217. Iegūts no: doi.org/10.1098/rspb.2004.2712

36. Jee, C. (2019). A facial recognition ban is coming to the US, says an AI policy advisor. MIT Technology Review. Iegūts no: https://www.technologyreview.com/s/614362/a-facial-recognitionban-is-coming-to-the-us-says-ai-policy-advisor/

37. Jenkins, R., Dowsett, A. J., Burton, M. (2018). How many faces do people know? Proceedings of the Royal Society B. 285(1888). Iegūts no: doi.org/10.1098/rspb.2018.1319

38. Johnson, M. H., Dziurawiec, S., Ellis H., Morton, J. (1991). Newborns' Preferential Tracking of Face-like Stimuli and Its Subsequent Decline. Cognition. 40(1/2), 1-19. Iegūts no: doi. org/10.1016/0010-0277(91)90045-6

39. Just over 56000 persons in the EU committed suicide. (2018). Eurostat. Iegūts no: https:// ec.europa.eu/eurostat/web/products-eurostat-news/-/DDN-20180716-1?inheritRedirect=true

40. Kaplan, R. (1999). Anorexia Nervosa, Infertility and Pregnancy. Medical Journal of Australia. 171(7), 391-392.

41. Karremans, J. C., Frankenhuis, W. E., Arons, S. (2010). Blind Men Prefer a Low Waistto-Hip Ratio. Evolution and Human Behavior. 31(3), 182-186. Iegūts no: doi.org/10.1016/j. evolhumbehav.2009.10.001

42. Kasperk, C., Helmboldt, A., Börcsök, I., Heuthe, S., Cloos, O., Niethard, F., Ziegler, R. (1997). Skeletal Site-Dependent Expression of the Androgen Receptor in Human Osteoblastic Cell Populations. Calcified Tissue International. 61(6), 464-473. Iegūts no: doi.org/10.1007/ s002239900369

43. Lassek W. D., Gaulin, S. J. C. (2009). Costs and Benefits of Fat-Free Muscle Mass in Men: Relationship to Mating Success, Dietary Requirements, and Native Immunity. Evolution and Human Behavior. 30(5), 322-328. Iegūts no: doi.org/10.1016/j.evolhumbehav.2009.04.002

44. Mader, S. S., Windelspecht, M. (2017). Human Biology. Mc Graw Hill.

45. Martin, J. (2019). Rare Diseases of the Immune System Genetics of Rare Autoimmune Diseases. Springer.

46. Meistere, D. (2017). Atzinums par likumprojektu “Sejas aizsegšanas ierobežojuma likums”. Rīga.

47. Morris, D. (1999). The Naked Ape. Delta.

48. Pagel, M., Bodmer, W. (2003). A Naked Ape Would Have Fewer Parasites. Proceedings of the Royal Society B: Biological Sciences. 270(1). Iegūts no: doi.org/10.1098/rsbl.2003.0041

49. Peplau, L. A., Frederick, D. A., Yee, C., Maisel, N., Lever, J., Ghavami, N. (2009). Body Image Satisfaction in Heterosexual, Gay, and Lesbian Adults. Archives of Sexual Behavior. 38(5), 713-725. Iegūts no: doi.org/10.1007/s10508-008-9378-1

50. Pētersone, I. (07.07.2019.) N̦irgāšanās skolā var beigties ar pašnāvību. LA.lv. Iegūts no: http:// www.la.lv/nirgasanas-skola-var-beigties-ar-pasnavibu

51. Psoriāzes izplatība palielinās, un tā nav tikai ādas slimība. Tvnet. 29.10.2019. Iegūts no: https:// www.tvnet.lv/6812870/psoriazes-izplatiba-palielinas-un-ta-nav-tikai-adas-slimiba 
Sabine Krilova, Andris Ziemelis. Vizuālā tēla

neaizskaramības sociāli biologiskie apsvērumi

52. Puts, D. A. (2010). Beauty and the Beast: Mechanisms of Sexual Selection in Humans. Evolution and Human Behavior. 31(3), 157-175. Iegūts no: doi.org/10.1016/j.evolhumbehav.2010.02.005

53. Raif-Meyer, A., Turner-Tretz, T., Ivedi, S. (2008). Press Release Issued by the Registrar Insufficient Redress in Lithuanian Breach of Privacy Judgments.

54. Rasnačs, Dz. (2016). Likumprojekta "Sejas aizsegšanas ierobežojuma likums” sākotnējās ietekmes novērtējuma ziṇojums (anotācija). Rīga.

55. Roehner, B. (2007). Driving Forces in Physical, Biological and Socio-Economic Phenomena. Cambridge University Press. Iegūts no: doi.org/10.1017/CBO9780511611148

56. Scheib, J. E., Gangestad, S. W., Thornhill, R. (1999). Facial Attractiveness, Symmetry and Cues of Good Genes. Proceedings of the Royal Society B: Biological Sciences. 266(1431), 1913-1917. Iegūts no: doi.org/10.1098/rspb.1999.0866

57. Singh, D. (1993). Adaptive Significance of Female Physical Attractiveness: Role of Waistto-Hip Ratio. Journal of Personality and Social Psychology. 65(2), 293-307. Iegūts no: doi. org/10.1037/0022-3514.65.2.293

58. Singh, D., Singh, D. (2006). Role of Body Fat and Body Shape on Judgment of Female Health and Attractiveness: An Evolutionary Perspective. Psychological Topics. 15(2), 331-350.

59. Smith, M. J. L., Perrett, D. I., Jones, B. C., Cornwell, R. E., Moore, F. R., Feinberg, D. R., Boothroyd, L. G. et al. (2006). Facial appearance is a cue to oestrogen levels in women. Proceedings of the Royal Society B: Biological Sciences. 273(1583), 135-140. Iegūts no: doi.org/10.1098/rspb.2005.3296

60. Soler, C., Nunez, M., Gutierrez, R., Nunez, J., Medina, P., Sancho, M., Alvarez J., Nunez, A. (2003). Facial attractiveness in men provides clues to semen quality. Evolution and Human Behavior. 24(3), 199-207. Iegūts no: doi.org/10.1016/S1090-5138(03)00013-8

61. Spitzer, B. L., Henderson, K. A., Zivian M. T. (1999). Gender Differences in Population versus Media Body Sizes: A Comparison over four decades. Sex Roles. 40(7), 545-565.

62. Students' Well-Being: PISA 2015 Results (III) OECD. (2017). Iegūts no: doi.org/http://dx.doi. org/10.1787/9789264273856-en IS

63. Sugiyama, L. S. (2015). Physical Attractiveness in Adaptationist Perspective. The Handbook of Evolutionary Psychology. 2, 2015, 292-343. Iegūts no: doi.org/10.1002/9780470939376.ch10

64. Swami, V., Frederick, D. A., Aavik, T., Alcalay, L., Allik, J., Anderson, D., Andrianto, S., et al. (2010). The Attractive Female Body Weight and Female Body Dissatisfaction in 26 Countries across 10 World Regions: Results of the International Body Project I. Personality and Social Psychology Bulletin. 36(3), 309-325. Iegūts no: doi.org/10.1177/0146167209359702

65. Tan, R. (2018). From France to Denmark, Bans on Full-face Muslim Veils are Spreading Across Europe. The Washington Post. Iegūts no: https://www.washingtonpost.com/world/2018/08/16/ france-denmark-bans-full-face-muslim-veils-are-spreading-across-europe/?arc404=true

66. Taqiuddin Al Hilali, M., Khan, M. M. (2002). The Noble Quran.

67. Vincent, T., Brown, J. (2005). Evolutionary Game Theory, Natural Selection, and Darwinian Dynamics. Cambridge University Press.

68. Voracek, M., Fisher, M. L. (2006). Success is All in the Measures: Androgenousness, Curvaceousness, and Starring Frequencies in Adult Media Actresses. Archives of Sexual Behavior. 35(3), 297-304. Iegūts no: doi.org/10.1007/s10508-006-9021-y

69. Whalen, R. E. (1966). Sexual Motivation. Psychological Review. 73(2), 151-163.

70. Zebrowitz, L. A., Hall, J. A., Murphy, N. A., Rhodes, G. (2002). Looking Smart and Looking Good: Facial Cues to Intelligence and Their Origins. Personality and Social Psychology Bulletin. 28(2), 238-249. Iegūts no: doi.org/10.1177/0146167202282009 